\title{
Malignancy-Associated Hypercalcemia Related with Receptor Activator of NF-KB Ligand (RANKL) Expression in T-Cell Acute Lymphoblastic Leukemia
}

\author{
Kenichi Tahara $^{a}$ Hiromi Koiso $^{\text {a }}$ Yo-hei Osaki ${ }^{a}$ Tomomi Sekigami ${ }^{a}$ Akihiko Yokohama ${ }^{a}$ \\ Takayuki Saitoh $^{\mathrm{b}}$ Norifumi Tsukamoto ${ }^{\mathrm{a}}$ Hirokazu Murakami ${ }^{\mathrm{b}}$ Masahiro Abe $^{\mathrm{c}}$ \\ Hiroshi Handa ${ }^{a}$

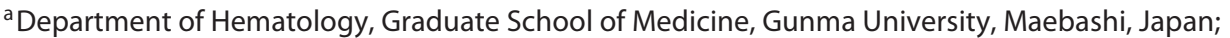 \\ ${ }^{b}$ Department of Health Science, Graduate School of Health Sciences, Gunma University, Maebashi, Japan; \\ 'Department of Medicine, Tokushima University, Tokushima, Japan
}

Malignancy-associated hypercalcemia (MAH) is a common paraneoplastic syndrome [1]; however, $\mathrm{MAH}$ is relatively rare in acute lymphoblastic leukemia (ALL) with an incidence of only $2.5-4.8 \%[2,3]$. There are 2 main categories of $\mathrm{MAH}$, namely, humoral hypercalcemia of malignancy (HHM), which is the most common cause of MAH and accounts for $80 \%$ of occurrences, and local osteolytic hypercalcemia (LOH) [4]. Humoral factors such as the parathyroid hormone-related protein (PTHrP) produced by tumor cells promote systemic bone resorption and causes HHM [5]. Meanwhile, inflammatory cytokines such as interleukin (IL)-1 $\beta$, IL-6, tumor necrosis factor (TNF)- $\alpha$, macrophage inflammatory protein (MIP)-1 $\alpha$, and MIP- $1 \beta$ produced by tumor cells cause $\mathrm{LOH}$ [6-9]. PTHrP can also cause $\mathrm{LOH}[4,10]$. The receptor activator of NF- $\kappa \mathrm{B}$ ligand (RANKL), which is expressed on the surface of bone marrow stromal cells such as osteoblasts, binds to the receptor activator of NF- $\kappa$ B (RANK) on the osteoclast precursors, induces differentiation and activation of osteoclasts [11], and is also one of the factors causing $\mathrm{LOH}$ [12]. The mechanism of
MAH in ALL has not been fully clarified because of its rarity. Herein, we report a case of precursor T-ALL complicated with hypercalcemia and investigate the factors triggering $\mathrm{MAH}$.

An 18-year-old man suffering from cervical lymph node swelling and night sweats was referred to our hospital. Physical examination revealed substantial swelling of the bilateral palatine tonsils and generalized lymphadenopathy. A complete blood cell count showed normal levels (hemoglobin concentration, $14.0 \mathrm{~g} / \mathrm{dL}$; white blood cell count, $6.8 \times 10^{9} / \mathrm{L}$ with no leukemic cells; platelet count, $\left.156 \times 10^{9} / \mathrm{L}\right)$. Human $\mathrm{T}$-cell leukemia virus type- 1 antibody was negative. Bone marrow aspiration biopsy showed hypercellular marrow with $40.7 \%$ leukemic cells. The leukemic cells were positive for cytoplasmic CD3, CD2, CD7, CD8, CD13, CD19, and CD79a, while negative for CD34, TdT, CD1, CD3, CD4, and MPO by flow-cytometric analysis. Immunohistochemical study revealed that the leukemic cells were positive for CD3 and TdT. Based on these data, he was diagnosed with T-ALL. The serum calcium level was normal at $9.5 \mathrm{mg} / \mathrm{dL}$ at the time of admis- sion but increased to $13.8 \mathrm{mg} / \mathrm{dL}$ with the increase of lactate dehydrogenase (LDH) before chemotherapy. Serum intact PTH and $1,25(\mathrm{OH})_{2}$ vitamin $\mathrm{D}_{3}$ levels were below normal ranges, and PTHrP was undetectable. Serum type I collagen cross-linked $\mathrm{N}$-telopeptides and urinary deoxypyridinoline were elevated, suggesting hypercalcemia induced by bone resorption. Therefore, inflammatory cytokines associated with bone metabolism were analyzed. The TNF- $\alpha$ level was within normal ranges, and IL-1 $\beta$ was undetectable. Immunohistochemical analysis revealed that the leukemic cells were positive for RANKL and MIP-1 $\beta$, weakly positive for MIP- $1 \alpha$, but negative for IL-1 $\beta$ (Fig. 1). Chemotherapy combined with bisphosphonate and calcitonin administration promptly reduced the serum calcium level to normal (Fig. 2). Swelling of the palatine tonsils and generalized lymphadenopathy were reduced with the improvement in hypercalcemia during induction chemotherapy. However, they reappeared concomitantly with the recurrence of hypercalcemia. Although he received re-induction chemotherapy, he did not achieve complete remission. He was
KARGER

(c) 2019 S. Karger AG, Basel

E-Mail karger@karger.com

www.karger.com/aha
Hiroshi Handa

3-39-15, Showa-machi

Maebashi, Gunma, 371-8511 (Japan)

E-Mail handahiroshi@gunma-u.ac.jp 
Fig. 1. Immunohistochemical staining for RANKL, MIP- $1 \beta$, MIP- $1 \alpha$, and IL- $1 \beta$ in the bone marrow. The leukemic cells were positive for RANKL (a) and MIP-1 $\beta$ (b), weakly positive for MIP-1a (c), but negative for IL-1 $\beta$ (d). $\times 1,000$.
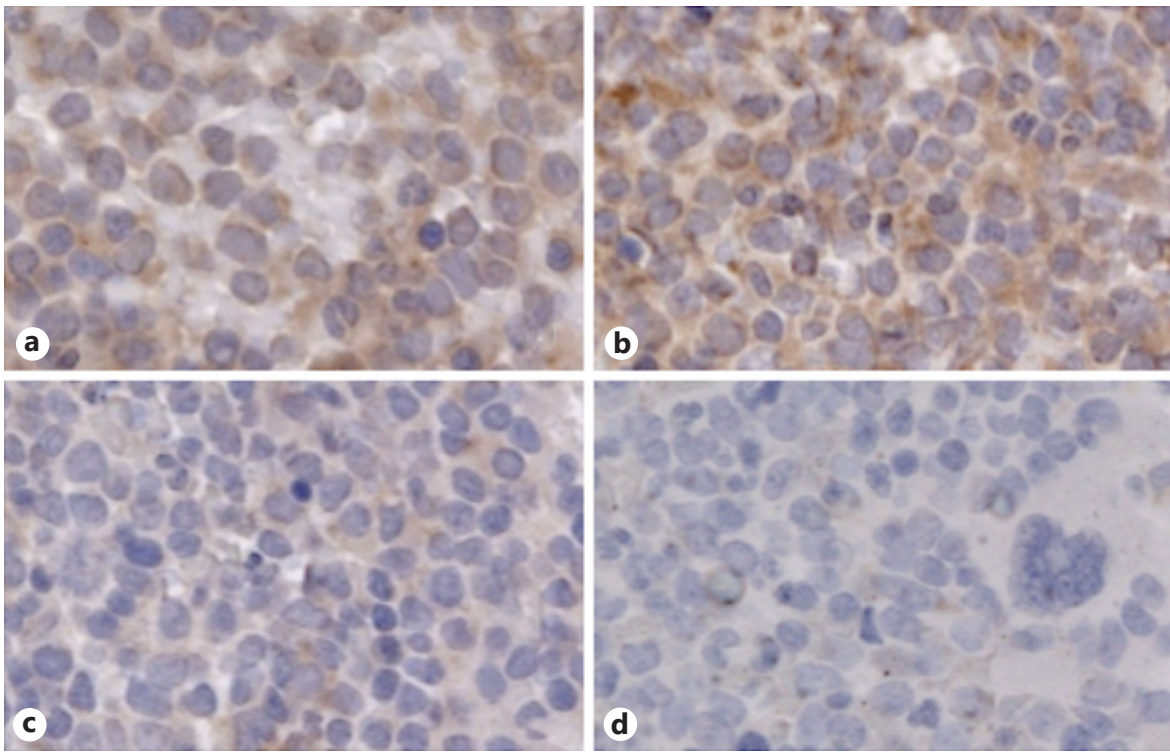

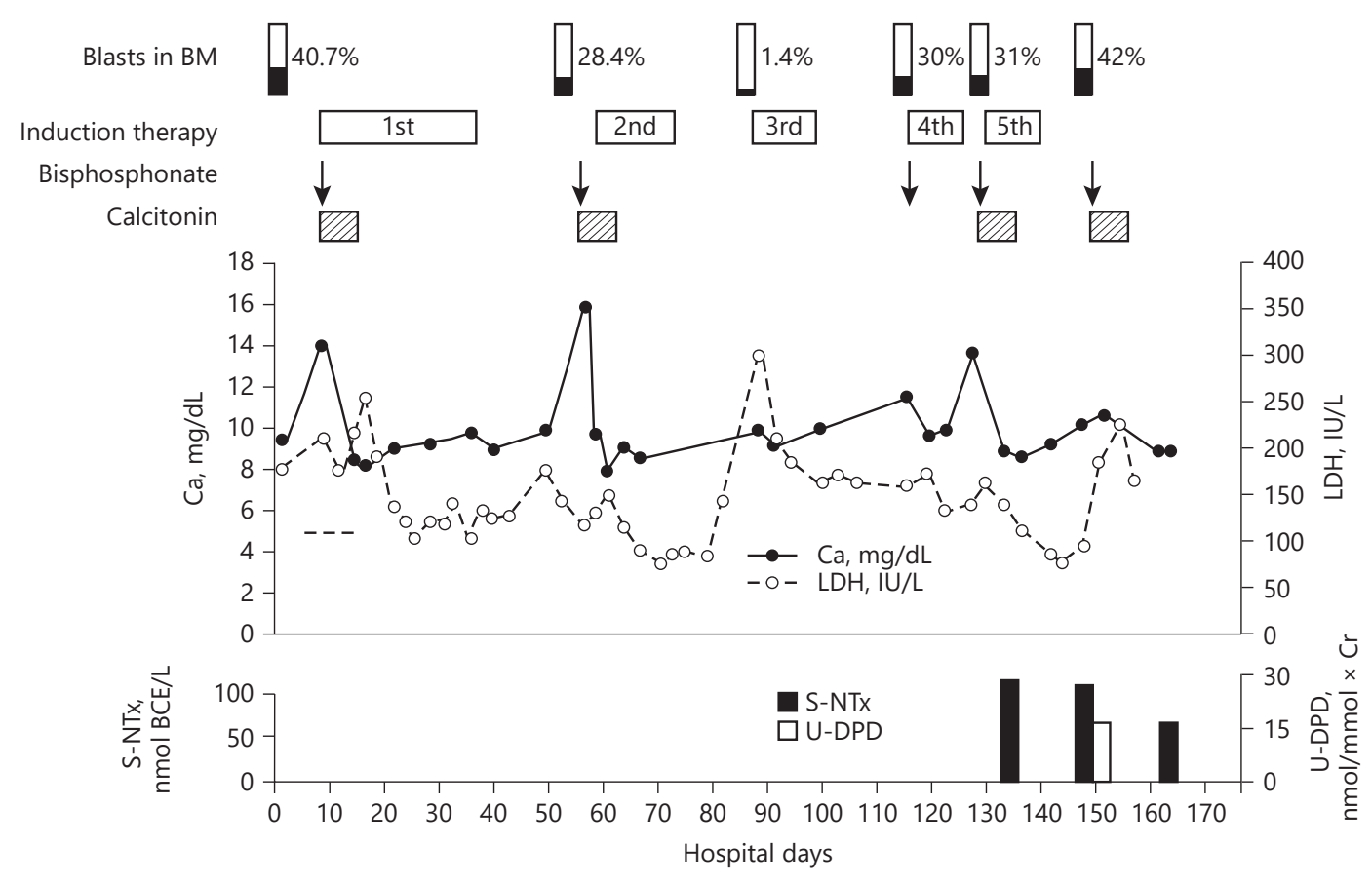

Fig. 2. Clinical course and laboratory data: levels of serum Ca, lactate dehydrogenase (LDH), serum type I collagen cross-linked N-telopeptides (S-NTx), and urinary deoxypyridinoline (U-DPD). BCE, bone collagen equivalent; BM, bone marrow.

transferred to another hospital for allogeneic hematopoietic stem cell transplantation.

The findings in this case suggested that $\mathrm{MAH}$ was induced by $\mathrm{LOH}$, which was in turn triggered by RANKL, MIP-1a, and
MIP-1 $\beta$ produced by leukemic cells. The hypercalcemia developed just before the elevation in $\mathrm{LDH}$, which is associated with leukemic cell proliferation, and serum calcium promptly decreased during chemotherapy. These data supported the hypoth- esis described above. However, computed tomography and 18-fluorodeoxyglucose positron emission tomography did not show any bone disease; thus, the contribution of HHM to hypercalcemia could not be ruled out. We also cannot rule out the 
possibility that the leukemic cells produced PTHrP and caused LOH, a mechanism which has been reported previously [13]. Measuring soluble RANKL in the serum and immunohistochemical analysis for PTHrP might be helpful to solve each question because PTHrP was undetectable in the serum.

\section{References}

1 Clines GA, Guise TA. Hypercalcaemia of malignancy and basic research on mechanisms responsible for osteolytic and osteoblastic metastasis to bone. Endocr Relat Cancer. 2005 Sep;12(3):549-83.

2 Hibi S, Funaki H, Ochiai-Kanai R, Ikushima S, Todo S, Sawada T, et al. Hypercalcemia in children presenting with acute lymphoblastic leukemia. Int J Hematol. 1997 Oct;66(3): 353-7.

3 Jordan GW. Serum calcium and phosphorus abnormalities in leukemia. Am J Med. 1966 Sep;41(3):381-90.

4 Stewart AF. Clinical practice. Hypercalcemia associated with cancer. N Engl J Med. 2005 Jan;352(4):373-9.

5 Rankin W, Grill V, Martin TJ. Parathyroid hormone-related protein and hypercalcemia. Cancer. 1997 Oct;80(8 Suppl):1564-71.
In conclusion, this is the first case of T-ALL in which the possible mechanism of MAH occurrence, which occurs through direct interaction between leukemic cells and osteoclasts, is proposed. Further biological studies are needed to validate this mechanism.

6 Cozzolino F, Torcia M, Aldinucci D, Rubartelli A, Miliani A, Shaw AR, et al. Production of interleukin-1 by bone marrow myeloma cells. Blood. 1989 Jul;74(1):380-7.

7 Ishimi Y, Miyaura C, Jin CH, Akatsu T, Abe E, Nakamura Y, et al. IL-6 is produced by osteoblasts and induces bone resorption. J Immunol. 1990 Nov;145(10):3297-303.

8 Johnson RA, Boyce BF, Mundy GR, Roodman GD. Tumors producing human tumor necrosis factor induced hypercalcemia and osteoclastic bone resorption in nude mice. Endocrinology. 1989 Mar;124(3):1424-7.

9 Abe M, Hiura K, Wilde J, Moriyama K, Hashimoto T, Ozaki S, et al. Role for macrophage inflammatory protein (MIP)-1alpha and MIP-1beta in the development of osteolytic lesions in multiple myeloma. Blood. 2002 Sep; 100(6):2195-202

\section{Acknowledgments}

We would like to thank Editage (www. editage.jp) for English language editing.

\section{Disclosure Statement}

The authors have no conflict of interest.
10 Akhtari M, Mansuri J, Newman KA, Guise TM, Seth P. Biology of breast cancer bone metastasis. Cancer Biol Ther. 2008 Jan;7(1):3-9.

11 Lacey DL, Timms E, Tan HL, Kelley MJ, Dunstan CR, Burgess T, et al. Osteoprotegerin ligand is a cytokine that regulates osteoclast differentiation and activation. Cell. 1998 Apr; 93(2):165-76.

12 Thosani S, Hu MI. Denosumab: a new agent in the management of hypercalcemia of malignancy. Future Oncol. 2015;11(21):2865-71.

13 Shimonodan H, Nagayama J, Nagatoshi Y, Hatanaka M, Takada A, Iguchi $\mathrm{H}$, et al. Acute lymphocytic leukemia in adolescence with multiple osteolytic lesions and hypercalcemia mediated by lymphoblast-producing parathyroid hormone-related peptide: a case report and review of the literature. Pediatr Blood Cancer. 2005 Sep;45(3):333-9. 